\title{
Place-Names and Objectivity in Historiography: The Case of Silesia in the 19th and 20th Centuries
}

TOMASZ KAMUSELLA

\begin{abstract}
On the basis of an introductory analysis of the intimate bond established between territory and the nation/nation-state, the author points out that the main instrument of this bonding is the naming of places in the national language. When writing about the past of an area, deciding to use this or that language to render place-names is not an innocent choice. This is especially true of the 19th and 20th centuries when nationalism became the only globally accepted ideology. Such a choice may amount to repossessing the past of a territory in the interest of this or that nation/nation-state.
\end{abstract}

In order to avoid an all too rarely noticed possibility that may compromise the ideal of objectivity in historiography, the author maintains that a practical solution in regard to the last two centuries in Europe is sticking to official forms of place-names in history writing. He shows the advantages and disadvantages of this method by drawing on the example of Silesia, a region that often changed hands among Prussia, Austria-Hungary, Germany, Poland and Czechoslovakia. He notes the most practical ways that various language forms of place-names have been used in a non-ideological way, with two reservations: that there does not seem to be any simple manner in which this method could be extended to periods prior to the 19th century and that it might be necessary to drop the official forms of place-names in favor of ethnic or dialect ones when focusing on non-dominant ethnic/regional groups.

The idea that the $[\ldots]$ people of the world fall naturally into a series of national groups is one of the dominating presuppositions of our time. (Potter, 1962: 924)

Smiling, disdainful, sublime, thinking of his King, of his Flag [...] he looked for the last time upon the screaming horde of black demons. (in Gann, 1969: 62-63) 
Veĺmi sa mi páčia tie rusínske piesne, ktoré spievajú tí Ukrajinci po tých našich slovenských dedinách...[1] (Vico in Kužel, 1999: 136)

\section{NATIONALISM AND LANGUAGE}

Nationalism came to the fore in world politics with the American and French revolutions, which created the nation-state (in the exemplary form of the United States and France) as the model unit of the political organization of the world with "naturally" carved-out populaces, i.e. the nation (Kohn, 1962). Albeit to this day it has not been deemed necessary to establish an official language in the US; nevertheless American English fills in this unacknowledged position. Similarly not much thought was given to French as a political factor in the wake of the revolution, but already in 1794 it was considered worthwhile prohibiting the use of any other languages but French (Edwards, 1994: 154).

Following the transformation of the Spanish and Portuguese colonies into nation-states in Latin America in the first half of the 19th century under the influence of both aforementioned revolutions (Anderson, 1991: 47-66), especially the French example took hold among the intellectuals, burghers and nobility in the Apennine Peninsula and in the German Confederation (Deutsches Bund) - the halfheartedly welcome successor to the Holy Roman Empire that Napoleon had dissolved in 1806 (Schulze, 1991: 48-55). Here, language in accordance with Ernst Moritz Arndt's words: What is the German fatherland?/ So name me thus my land!/ Wherever rings the German tongue/ And God in Heaven sings,/ So shall it be, so shall it be,/ It shall be all Germany (in Fishman, 1996: 166) and with Friedrich Schleiermacher's statement that one can truly be loyal only to one's nation (Kedourie, 1993: 57), became the foundation of nation- and nationstate-building (Kamusella, 2000).

In nation-states based on civic nationalism, the national language may be the very mainstay of this ideology (as in France), its value may be largely utilitarian only (as in the US), or it may not exist in the singular at all (as in Switzerland). But in nation-states steeped in ethnic nationalism the national language invariably functions as a significant (if not the most important) constituent of such an ideology. This situation reflects the different ways in which nation-states based on civic and ethnic nationalism usually came into being. The former - territorial states with highly centralized administrations - overhauled their populations into 
nations, and, thus, became nation-states. The latter started as national movements, which created nations that struggled to clad themselves with their own nation-states (cf. Gellner, 1983; Hroch, 1985).

In civic nationalism, it is the borders of the already existing polity that outline the spatial extent of the nation-/nation-state-in-construction. This differs starkly from the case of ethnic nationalism, where the nation-inmaking does not match any existing polity, which tends to be spatially either much bigger or smaller than this nation. Thus, the territorial extent of such a nation is usually correlated with the geographic distribution of people speaking dialects considered to be of the national language of the postulated nation. The spread of these national-language-speakers is also the basis for claims to a nation-state that would contain all of them. Without going into details, which do not need to concern us here, one may remark that the construction of nation-states based on ethnic nationalism entails the destruction or vast territorial overhauling of already existing polities. On the other hand, builders of nations steeped in the same kind of nationalism conveniently overlook that before the rise of standard languages, subdialects change gradually from village to village, creating vast dialect continua usually corresponding to whole language groups and not a single standard language (Crystal, 1987: 25).

The emergence of standard languages based on spoken vernaculars used in the centers of political power in the centralized territorial states, or promoted by early activists of ethnic national movements as "most representative" of their postulated nations, was sparked by modernization. The development of a modern capitalist economy grounded in industrialization would not have been possible without mobile labor/consumers. Thus, the processes of modernization that fortified the centralized state caused it to contribute to these very processes, which made it stronger economically and militarily. Soon population stratification on the basis of birthright gave way to equalization by overhauling them as citizens formed through popular education and compulsory military service (Deutsch, 1966). The means by which the legally assured mobility of the citizenry was guaranteed were rapid and mass transportation and communication (Breuilly, 1993: 19-52; Pierson, 1996: 35-63).

For this mobility to be effective and equally useful for the state, the economy and the citizenry as a whole, all citizens had to share one idiom only, as language is the instrument of interpersonal communication. In 
the past, one's vernacular (spoken subdialect), which was limited to one's village, was enough for the overwhelmingly immobile peasantry, whereas the members of the estates spoke and wrote in chancellery/literary languages largely unrelated to these vernaculars (e.g. in Latin, Old Church Slavonic, Osmanlica) that allowed them mobility within large empires and on a continental or even intercontinental scale (Armstrong, 1982: 241-282).

Involving all the populace of the state in modern economic, social and political life required the development of a standard language common for all and, ideally, close to the vernaculars for the sake of rapid comprehension. The standardization and spread of such a language gradually inculcated in the populace was made possible through popular education, the conscript army, centralized state administration and the mass media (Deutsch, 1966; Kamusella, 1999).

Eventually, a standard language formed by a succession of codifiers (who spawned the first dictionaries and grammars as well as put this language into use in newspapers and books before elevating it to the level of the only medium of administration and education) became the national language. Especially in nation-states based on ethnic nationalism, the national language began to be perceived as a symbol of nationhood equal in rank with the national flag, national coat-of-arms and the national anthem. Reified as such, its paramount significance is hard to overestimate - the very national anthem was sung in it, and it was this language which provided the nation with the 'proof' where the borders of its nation state were, thus, indirectly limiting the locations where the national flag could be unfurled and the national coat-of-arms displayed (cf. Billig, 1995).

\section{LANGUAGE AND TERRITORY}

Because almost every Central European nationalism is ethnic in character (Kamusella, 2000), standard/national languages are the main instruments of ennationalization, i.e. making a given population into a nation and a given territory into a nation/nation-state (cf. Kamusella, 1999a). The native-level command of a national language makes one of a nation, while the lack of this mastery in children/descendants nevertheless claiming allegiance to a nation causes the administration of the nation- 
state/activists of the nation to berate them that they should maintain "appropriate" knowledge of their "mother tongue."

But the connection between the nation/nation-state and the physical territory is not enacted only through the overwhelming presence of the speakers of the national language. The national language is the written language par excellence, which is clearly visible in the fact that while there are about 190 states in the world, the most significant written languages number 200, thus, closely corresponding to the former number (Crystal, 1987: 284; Enriquez, 1999: 30). Hence, the written form of the national language can be physically impressed on the territory of the nation-state, in this way making it national and/or claiming it for a nation/nationstate in making.

The most obvious method in this respect amounts to seizing the practice of naming places for the sake of nationalism (cf. Wickham, 1997). Here, once again, there is a gulf of difference between nation-states steeped in civic and ethnic nationalism. In the former states, as, for instance, in the US, every place-name is equally easily accepted after having been transcribed into the Latin alphabet if inhabitants of a locality agree on it, even though it may be unpronounceable for an Englishspeaker, often leading to the rise of an Anglicized version of the original pronunciation of the place-name. Hence, apart from English place-names (New York), one can also find in the US ones in Native American languages (Massachusetts), Hawaiian (Honolulu), Spanish (Los Angeles), French (Lafourche), Russian (Tolstoi), German (Bismarck), Polish (Panna Maria), Swedish (Vasa), etc. (Stewart, 1970).

On the contrary, ethnic nationalism requires the comprehensive "translating" of the landscape into the national language of the nationstate in which this territory is contained. This is effected with little or altogether no respect for previous naming traditions. In this manner, not only is landscape repossessed by the nation-state, but through the use of the current national forms of the place-names for talking about a past which was not national, the fact is forgotten and the past is (re-)written so as to pose as part of the "primordial" history of the nation/nation-state (cf. Berger, 1999; Kushner, 1997). As Hobsbawm and Ranger succinctly propose: the past is invented for contemporary aims and needs usually dictated by nationalism (1983). 
It is thus not surprising that, when casually asked, students identify such textbook-famous events as the Battle of Austerlitz (1805) or the Battle of Königgrätz (1866) with some unspecified localities in Austria or (maybe) Germany. It is rarely pointed out in a classroom that today both towns, now known as Slavkov and Hradec Králové, are located in the Czech Republic. Similarly, the significant World War I battles of Tannenberg (1914) and Ivanogorod (1915), on the eastern front, tend to be associated with Germany and Russia, respectively, though, at present, both the localities known as Stębark and Dęblin, are located in Poland.

No such mistakes are committed in the case of the western front because Ypres is still Ypres in Belgium, and Verdun is still Verdun in France. France was established as a nation-state at the turn from the 18th to the 19th century and Belgium in 1830, and since then their national territories with the corresponding networks of place-names have remained largely unchanged. Fate, however, dealt a different history to Central Europe, as noted above. During the 19th century, Vienna strove to preserve as much of the tradition of the Holy Roman Empire as possible. Incidentally, from the time of the absolutist Theresian and Josephine reforms at the close of the 18th century, this meant preserving place-names in Germanized forms. However, the destruction of the German Confederation (1866) and the establishment of the German nation-state (1871) twisted Francis Joseph I's emperor's arm enough to make some concessions to nationalism. After 1867 Magyarized forms of place-names in Transleithania became official, and Polish ones in Galicia. In 1882 Czech forms of place-names in Bohemia were accepted alongside their German counterparts, and a similar development unfolded in Moravia after 1905. But the full thrust of the national change came, of course, with the break-up of Austria-Hungary and the annexations of the formerly Russian and German territories as the basis for the springing up of the new nation-states of Austria, Czechoslovakia, Estonia, Finland, Hungary, Latvia, Lithuania, Poland and Yugoslavia. Consequently, the Russian forms of place-names were banned from this area and the German and Magyar forms limited, respectively, to the postwar Germany and Austria, and Hungary. 


\section{HISTORIOGRAPHY AN D OBJECTIVITY}

Despite these ideological uses of place-names, which form a rarely noticed part of everyday reality, the historian is in danger of glossing over their usualness as it seems so banal (cf. Billig, 1995). This approach may easily compromise the ideal of objectivity, in line with which the historian is supposed to analyze the past impartially and dispassionately. If it comes to that, she does not look at the past any more but at her musings and wishful thinking about the past. This forms excellent fodder for politics, propaganda or legends but is not a base for sound scholarship. Obviously, absolute objectivity in the Enlightenment tradition of the search for the Truth is not possible because we know only through the inherently a-rational medium of language (Lakoff, 1980); thus, all our knowledge is discursive in character (Foucault, 1977). What is more, the retrieval capacity of the human brain, though vast, is limited and abysmally diminutive in comparison to the whole of the earth and let alone the universe. We can manage only sketchy maps/interpretations of reality because to reflect something of its every tiny detail one would have to re-construct this piece of reality in its entirety.

But the impossibility of absolute knowledge should not deter one from improving one's analytical instruments as long as it is viable and practical. This is especially true of historiography, the simplistic practice of which may replace the historian with a propagandist or, worse, turn the former into the latter.

In this article I have been concentrating on the problematic of placenames so as to expose how they can and have been used ideologically in the context of various nationalisms, as well as exposing the errors that crop up when one uses the present-day forms of place-names and applies them to various moments in the past when they did not obtain.[2] My focus is Silesia because knowing the problematic of this region quite intimately, not only can I present the complexity of the issues of its placenames but also wrap up with some tentative hints about how to avoid the pitfalls of the unreflective use of place-names.

SILESIA'S PLACE-NAMES AND NATIONALISM

Before the rise of nationalism and the centralized territorial state, placenames were of more utilitarian than ideological value. They were used 
for topographic orientation, improving the administration of delimited territories, establishing unambiguous borders, and collecting taxes. Because most of the population of premodern Europe was illiterate and quite immobile and because their travels tended to be limited to the vicinity of their place of residence or to villages around the hamlet where they had been born, it was enough to use the names of the frequented localities in their local dialect forms. On the other hand, members of the estates (natio) having to administer the state and their own lands had to standardize place-names in order to avoid ownership disputes or double taxation should one locality have two variegated names.

This standardization of place-names was effected through committing them to parchment, and at that time the only widespread written language extant in Western and Central Europe was Latin.[3] Hence, in writing down place-names one strove to convey their original phonetic realization in Latin spelling, which led to a certain Latinization of the official forms of place-names. For instance Wrocław (Breslau) was rendered as Vratislavia. Because in the 12th century more original literature had started to be written in chancery German and this language began to be more widely used in administering along with Latin, one started to write place-names in German spelling too, especially in the Holy Roman Empire and in the Central and Eastern European areas where settlers from this empire established their villages and towns. In multilingual localities oral Germanic and Slavic versions were used along with the official Latinized form of the place-name. Due to the lack of standardized rules of spelling to which all users could subscribe, often Latin and German versions of a given place-name varied quite widely. The first 16th- and 17th-century maps of Silesia (Mrass, 1995) and Knie's topographic dictionary (1845) are the best introduction to the Latin and various early German forms of the Silesian place-names.

On the other hand, at the height of the Renaissance when the fad was to look for and/or invent ancient roots of one's locality and region, Ptolemy's map of the world became the source of inspiration. In 1503 Breslau (Wrocław) humanist Sigismundus Fagilucus (Sigismund Buchwald)[4] identified Breslau (Wrocław) with the Ptolemaic town of Budorgis.[5] The Oder (Odra) was found to be identical with the Ptolemaic Viadrus, and the Sudetic Mountains received their name from the "Sudetes," which on Ptolemy's map seem to be separating Bohemia from Silesia. When no "original" ancient place-name could be found for a smaller town, the learned resorted to translating extant place-names into 
Latin or Greek, for instance, Ziegenhals (Głuchołazy) became Civitas Capricollis, and Grünberg (Zielona Góra) Prasia Elysorium or Thalloris.[6] Also Tacitus's Germania proved to be a useful source of inspiration. In 1558 Philipp Melanchton, known as Praeceptor Germaniae, identified the Silesians (whose name he wrote in Latin as Silesii) with the Elysii from Tacitus's work. Consequently, since that time the name Elysium was used to denote Silesia until the waning of this usage at the turn of the 20th century.

The superimposition of classical veneer on the Silesian onomastic reality intensified in the 18th century under the influence of rapid administrative reforms. They came after Prussia had wrenched most of Silesia out of the grasp of Vienna in 1740-42, leaving the latter with oneeighth of the region's territory.[7] The concomitant spread of literacy gave an ever-growing circle of Silesians access to the printed word, bringing about the establishment of the first Silesian newspapers and an intensification in the use of antiquity for contemporary needs. What is more, the varied geographical configuration of the land facilitated such comparisons. Thus, Silesia, known as Elysium, was often likened to Arcadia, especially in the context of numerous sheep herds in the Sudetic Mountains. The Silesians substituted the Greek Helicon and Apollo of Delphi with the Sudetes and the refined version of the mythic Sudetic mountain spirit Rübezahl (Liczyrzepa). Breslau (Wrocław) excelled as old Athens and the Jablunka (Jablunkov) Pass provided the perfect location for Silesia's Thermopylae. These comparisons with ancient places also extended to people. Hence, the Silesian Martin Opitz (1597-1639) dubbed the "father of German poetry," was also lauded as the German Homer, and such Baroque Silesian poets as Christian Hofman von Hofmannswaldau (1616-1679) and Daniel Casper von Lohenstein (16351683), who excelled in writing tragedies, were likened to Euripides and Sophocles, respectively (Conrads, 1994: 250-152; Malicki, 1987: 8-9).

Modernization, which entered Silesia after the Prussian conquest and had become the framework of economic, social and political change in Prussian and Austrian Silesia by the second half of the 19th century, also introduced German as the official language in the course of the efforts leading to the establishment of the Little German nation-state in 1871. This standard language gradually became the only medium of the burgeoning civil service and popular education. On the other hand, German was used in the press and the army. After 1871, in Germany 
education and registration of births, marriages and deaths were wrestled away from the Catholic and Protestant churches by the state, all the more fortifying the dominance of the official language. In the case of Germany, it was also the national language of this nation-state.

Modernization in the sphere of language resulted in the command of standard German spreading, and in the standardization of the forms of Silesian place-names in conformity with German spelling. The same also applied to writing down surnames and choosing appropriate forms of Christian names for children.

Due to the development of Polish and Czech nationalisms in Silesia at the turn of the 20th century, an increasing number of maps of Silesia with Polish and Czech forms of the main Silesian place-names were produced. The basis for this was old Slavic usages ((re-)written down in standard Czech and Polish) as chancery Czech (i.e. Bohemian) was an official language (along Latin and German) of Upper Silesia from the 16th to 18th centuries, and some princely courts of Upper Silesia also used chancery Polish. What is more, from 1849 to 1873 standard Polish and the Moravian language[8] were quite widely used in education and church life in Upper Silesia, which prompted Slavic-speaking inhabitants to write down the names of their localities using one of these Slavic spelling systems rather than German. Knie notes these aforementioned old Slavic usages (1845).

However, with the clash of Polish, Czech and German nationalisms in Silesia, Polish and Czech nationalists tended to invent Slavic names for localities bearing unambiguously German names with no Slavic counterparts. But the latter, the Czechs, had a penchant for writing the German versions down with Czech spelling (e.g. Münsterberg Minsterberk in Czech, Ziębice in Polish, Frankenstein - Frankštein in Czech, Ząbkowice in Polish. For Polish versions of Silesian place-names used prior to 1918 see Gregor (1904) and Haardt (c. 1908: map No. 31), and for Czech ones see Anon. 1905: map bet. pp. 368-369). After World War I, Czechoslovakia's incorporation of its part of Austrian Silesia and the Hultschiner Ländchen (Hlučínsko) (transferred from Upper Silesia) prompted the phasing out of the German versions of the place-names and the almost instantaneous introduction of Czech ones as the only official ones. The Polish authorities followed the same route in the parts of Lower Silesia, Upper Silesia and East Silesia that had been granted to Poland and mostly incorporated into the Silesian Voivodeship. This rapid 
Polonization/Czechization of place-names was a surprise to many a Szlonzok, Slunzak, Morawec,[9] not to mention to the German-speaking Silesians. The latter observed how their homeland was turned into a foreign place in a matter of days, while the former found their homeland somehow un-homely, as Warsaw and Prague did not care to utilize the extant dialectal Slavic versions of the place-names but rather went for the versions written down in the spellings conforming with standard Polish and Czech, in the interest of fortifying the unity of the newly established nation-states. So Königshütte became Królewska Huta/Chorzów rather than Królefskou Chuta, Piekar - Piekary rather than Pekary, Kattowitz Katowice rather than Katowicy, Tarnowitz - Tarnowskie Góry rather than Tarnowsky Góry etc. For more on local dialectal forms of Upper Silesian place names, see Olesch (1958-1959, Vol I: 123-127).

Few place-names were Germanized prior to 1933, but that was rather due to the wishes of inhabitants of a locality and not to administrative pressure. The most famous example is the city of Hindenburg that received its name in 1915 in honor of the general who had saved Upper Silesia from the incursion of the Russian army at the onset of the Great War. Prior to that date it was Zabrze.[10] In 1933 Hitler set out to actualize the program of Gleichschaltung (homogenization), which was to produce a unified nation-state on the basis of a homogenous German Volksgemeinschaft (nationhood) no longer sub-divided with regional, linguistic, dialectal or ethnic differences. The Germanizing changes in the forms of the too Slavic-sounding Silesian place-names, carried out in 1934-1939, are noted in Barran (1993: 342-349). After the Munich agreement Germany regained the Hlučínsko (Hultschiner Ländchen) and seized West Silesia, and Poland obtained most of the Czechoslovak part of East Silesia and the area north of Čadca (Csacza). Berlin reintroduced there the German versions of the place-names, while Warsaw Polonized the Czech and Slovak ones. Czech, German and Polish versions of placenames in Czech Silesia can be found in in Pfohl (1987) and Hosák (19701980).

During World War II, when Berlin gained the enlarged Silesian Voivodeship and incorporated it with the adjacent counties of the Cracow and Kielce Voivodeships into the Province of Silesia, the predivision German versions of the place-names were re-introduced in the Upper Silesian and East Silesian sections of the erstwhile Silesian Voivodeship, while only the most important place-names were 
Germanized in the Kielce and Cracow counties. Regarding changes in these non-Silesian counties, see Stüttgen (1976).

After 1945 Prague regained all of its part of interwar Silesia, and the Czech versions of the place-names returned. On the other hand, Warsaw not only recovered its part of the interwar Silesian Voivodeship (less what it had seized from Czechoslovakia in 1938), but also was granted all of Silesia east of the Oder-Neisse line. So besides, the reintroduction of the interwar place-namesion the territory of the prewar Silesian Voivodeship, Warsaw set out on a course of Polonizing all the placenames in the newly-gained sections of Silesia. The Polish and German versions of these place-names in Upper and Lower Silesia one can find in Choroś (1997),[11] Choroś (1995)[12] and Kaemmerer (1988), while a thorough treatment of various Polish and German alternatives of the place-names in the territory of the interwar Oppeln (Opole) Regency[13] is available in Hanich (1997).

These aforementioned dictionaries usually only list the names of localities. If one is looking for the various linguistic versions of names of rivers, lakes and mountains, one should consult Battek (1998). While the Sorbs are marginal to the history of Silesia, some areas in the west of Lower Silesia were inhabited by them, and the curious reader may look up the Sorbian versions of Lower Silesian place-names (especially west of the Oder-Neisse line) in Eichler (1987).

This list of references of Silesian place-names is thorough but not exhaustive. However, even a full list of them would be of no help when it comes to deciding on the linguistic versions of the name of an obscure locality or geographical object. Then it is frequently essential to resort to comparing maps and atlases that were published before 1918, during the interwar period, during World War II and after 1945 in Austria-Hungary, Germany, Poland and Czecho(slovakia).

HOW TO USE PLACE-NAMES MORE OBJECTIVELY

There are no ready-made answers to this problem as only recently authors writing on traditionally multilingual areas with various written standards started tackling this problem. In his Southeastern Europe under Ottoman Rule, 1354-1804 (1977), Peter F. Sugar uses the present-day forms 
of the place-names but in a "Glossary of Geographic Names" notes the various linguistic forms used in this area during the period he covers. On the other hand, Kann and David in The Peoples of the Eastern Habsburg Lands, 1526-1918 (1984) are quite eclectic. Sometimes they use present-day forms of place-names appending them in parentheses with the forms that were used in the period they write about. Other times they invert this practice, putting the modern form into parentheses or doing away with the modern form altogether and sticking only to the form used in the past. Ambitiously, on the maps in his Historical Atlas of East Central Europe (1995), Paul Robert Magocsi presents the present-day forms of the names of localities appending them in parentheses with as many of their historical forms as possible. He also lists all of them in the index with appropriate cross-references in twenty-six languages. Last but not least, Norman Davies in The Isles: A History (1999) uses the linguistic forms of place-names which were used in various periods of time by different ethnic groups/nations in the regions of their abode/domination within the geographical range of today's United Kingdom and Ireland. He lists the forms with their English counterparts according to the chapters where they are employed (p. 1094-5), and gathers some of them in a list in which their alternative forms are shown in nine languages (p. 1093). Moreover, not to be guilty of anachronism when he writes about the prehistoric period from which no written/oral records on place-names survive, Davies transposes all the place-names he had to use in this context into imaginary but time-neutral forms (cf. p. xlii).

To return to Silesia, in my $\mathrm{PhD}$ dissertation entitled The Emergence of the National and Ethnic Groups in Silesia 1848-1918, place-names are given in the form that was official at the period of time indicated in the narrative. Because of the period in question, most frequently the German versions of place-names in Prussian and Austrian Silesia are used. In parentheses they are appended with the current form of the place-name, which is usually Polish or Czech. For instance, Breslau (Wrocław), Troppau (Opava). On the other hand, if a place-name from the westernmost part of Silesia west of the Oder-Neisse line is mentioned, it is not appended with a Polish/Czech version in parentheses as this part of Silesia still remains in Germany, e.g. Hoyerswerda. To maintain consistency, when I mention a Polish/Czech version of a Silesian placename in the present-day context, it is followed by its German counterpart, for example, Wrocław (Breslau), Opava (Troppau). 
This straightforward approach is a bit complicated in certain cases. For instance, when I talk about Görlitz before 1945, the Polish name Zgorzelec is given in parentheses. But, subsequently, Görlitz and Zgorzelec are mentioned independently as the Polish-German now border splits what was once one city into two separate urban organisms. So the former is given as Görlitz only and the latter is appended with the German version of this place-name, i.e. Zgorzelec (Görlitz). A similar case is posed by Teschen (Cieszyn/Těšín). Prior to 1920 it was one city, but afterwards the Polish-Czechoslovak border cut it in two so that sometimes I speak of Cieszyn (Teschen) and other times of Těšín (Teschen).

Not to complicate matters too much, Bielitz is appended with the Polish form Bielsko in parentheses, and not with the more correct one Bielsko-Biała, which came into being after the merger of Bielsko (Bielitz) with Biała (Biala) in 1951. The same is true of some changes in the official forms of place-names that were not valid for too long. Hence, Kattowitz is appended with the Polish form Katowice without any mentioning of Stalinogród, which was the official name of the city from 1953 to 1956 conferred in honor of Joseph Stalin. Similarly, Kędzierzyn is appended with the German form Kandrzin rather than Heydebreck, which was valid only for 11 years. On the other hand, when I talk about this town after the change, i.e. in the period 1934-1945, the official form Heydebreck is used with the Polish form Kędzierzyn in parentheses. Also when Katowice was Stalinogród, I refer to Stalinogród (Kattowitz).

When the narrative ventures into times earlier than the period under study, the fact that the Silesian place-names had Slavic characters before they became German/ic-sounding is not shown by the Latinized or recorded forms of these place-names found in contemporary sources but rather by the use of the modern Slavic (i.e. Polish or Czech) versions of these place-names. So before the 13th century it is Wrocław (Breslau) rather than the then current and widely varying forms Wrotizlava, Vuartizlau, Wrotizlauensis, Frodezlau, Brezlawensis, Vratizlau, Wrezlawe, Vratizlauia, Verzlaue, Vroczlauiensis, Wrezlau, Wratislauienis, Urozlau, Wratizlaw, Wratisalw, Bretlaensis (Stoob, 1995: 17) in order to avoid unnecessary confusion.

Considering the neighboring lands with which the history of Silesia more or less intensively interacted, the rule of following the use of official names only is also observed. Hence, in the case of Wielkopolska before 
1918 the German forms are used: Posen (Poznań) and Gnesen (Gniezno). In Bohemia the same pattern is followed: Reichenberg (Liberec) but only until 1882 when Czech gained official language status along with German in Bohemia. After that year I speak rather of Liberec (Reichenberg). The case is even clearer in Galicia, where Polish became a practically dominant official language (along with the much less used German) in 1869. So before that year the German form is the main one: Auschwitz (Oświęcim), and afterward the Polish one: Oświęcim (Auschwitz). But in the case of Lviv, which is a Ukrainian city today, prior to 1869 the notation is Lemberg (Lviv), and after that year: Lwów (Lviv) so as not to complicate the overall system of presenting placenames in this work. Regarding the various language forms of the main place-names in Central and Eastern Europe in the 19th and 20th century, one is advised to consult Batowski (1964).

In my dissertation the aforementioned rules do not straightforwardly apply to the place-names in the Vistula Land (i.e. Congress Poland) in the Russian empire, where Russified place-names or Polish place-names written in the Cyrillic script became the standard when Russian was introduced as the only official language in this area in 1865. Fidelity to the afore-sketched rules would demand transcribing the names from Russian (i.e. from the Cyrillic into the Latin script as employed in English) and appending them with the current Polish counterpart, e.g. Lomzha (Łomża), Kieltse (Kielce). But because the main focus of the work is on Silesia and such a solution could make some passages unjustifiably unintelligible, I decided to stick to the names in Polish spelling unless a given place name was located outside today's Poland, for instance, Wilno (Vilnius). But if it was dramatically Russified (as very few were), I stick to the Russian form transcribed into English spelling and give the Polish counterpart in parentheses, e.g. Ivanogorod (Dęblin).

In the case of place-names with extant Anglicized forms (Cracow, Prague, Warsaw, Budapest), I use them throughout the work without giving any other language versions of such place-names, as they are usually quite well known.

I am aware that sticking to official forms of place-names and their present-day forms cannot do justice to all the changes to which they have been subjected, let alone reflect dialectal usages or usages current in the languages of minorities (e.g. in Yiddish,[14] Armenian or Romani), but my dissertation not being a tract on onomastics in politics, it was as much 
as could be done to do justice to the linguistic variety in place-names without making the text utterly unreadable.

\section{CONCLUSION}

As can be seen from the above, nationalism not only influences one's environs through place-names expressed in accordance with the national language in the nation-state where one lives, but also the non-national past that happens to be congruent with the territorial extent of this nation-state. This often leads to the anachronistic use of present-day forms of place-names in inappropriate contexts in the past, thus causing national homogenization and the wholesale repossession of the past for the sake of today's nation/nation-state.

Having noted that this may endanger the objectivity of history writing, I propose to avoid this unwelcome possibility through the regular employment of the forms of place-names that were official at a given point in time and space to which we refer. There are two basic ways to do it, through:

1. writing the place-name in its official form and appending it with the present-day form in parentheses (this is the form I prefer);

2. using the present-day official form of the place-name in all the historical contexts and appending the text with a list in which the historical forms of the place-names are correlated with the modern ones.

The drawback of the former method is that it is complicated and can discourage the lay reader; and of the latter - the fact that such a list more often than not may never be referred to by the reader. A fair compromise is offered by another approach, in which a place-name is appended with the present-day form in parentheses when it is mentioned for the first time, and a concordance list of all the used forms of the mentioned placenames included at the end of the text.

I have tried to illustrate the practicalities and difficulties when it comes to using these techniques with the example of my $\mathrm{PhD}$ dissertation, in which I employed the first method. Also as noted in the title of this article, all these methods are most viable for the last two centuries only because the territorial state emerged in full after the Peace 
of Westphalia (1648) and the first standard languages connected to such states in the 18th century. Moreover, the direct link between the territorial state and culture/ethnicity represented by the standard language was decisively forged on the basis of nationalism only in the 19th century.

I do not have a ready-made answer for how best to present placenames in earlier historical contexts. I surmise that it is unadvisable to unreflectively use present-day place-names and suggest that if the period one is writing about is not too broad, it can be practical to stick to the forms that were consistently employed on contemporary maps, in documents and other extant texts. But only very few names of the most important cities/regions/geographical objects retained stable forms in pre-modern times. When one is writing about an extensive territory over a long period of time, it may be necessary to use the present-day forms of the place-names imaginatively. For instance, when I write about Silesia prior to the 14th century, I use the present-day Polish forms of the placenames not to claim that they were such but to emphasize the largely Slavic character of this land. In the later period I switch to the German forms of the place-names as employed up to 1945 in order to stress the increasingly Germanic (not German) character of Silesia.

And if one focuses on the past of an ethnic group which never dominated its landscape because it was effectively controlled by others, got assimilated or did not establish its own territorial or nation-state, one may write more objectively about such an ethnic group employing the forms of place-names which were commonly used by members of the group, usually accommodated to the spelling and pronunciation of their language. One can easily follow this advice when an ethnic group had a written tradition, as is true of the Yiddish-speaking Jews and Armenians in Central and Eastern Europe or the Morawecs in Silesia. In other cases it may be impossible unless the group concerned has survived to this day and retains their own oral forms of place-names that have been noted in a dictionary of their unwritten ethnolect (specific dialect/language form of this group closely connected to its ethnicity). In Central and Eastern Europe this is true of the Roma and in Silesia of the Szlonzoks and the Slunzaks.

But when no written documents survive and the transmission of oral history was breached as happened time and again all over the world when territories were seized and colonized/repopulated by Europeans, 
the historian faces the difficult question of how to write about the past of these territories and their populaces without succumbing to Eurocentrism. Davies's proposal to invent time-neutral forms of placenames is a first step, but it is not a final or even very practical answer to this difficult methodological issue. I hope that more elaboration on it by intrigued researchers and scholars will bring forth interesting results in the near future.

And though the question of how to use place-names and their various forms in historiography may seem minor, I trust that with this article I have managed to point out the wide-ranging ideological effects of the anachronistic use of place-names, which can adversely influence objectivity in history writing. Any new methods developed in this field may contribute to making historiography a more universal tool that the scholar will be able to apply not only to Europe and cultures with written traditions but also to the "people without history" (Wolf, 1982), whom traditional historiography has deprived of the little voice they had, first, in the interest of colonial empires, and, then, in the interest of the West poised against the Rest (cf. Huntington, 1996).

\section{EN D NOTES}

[1] "I like very much the Rusyn (Ruthenian) songs, which Ukrainians sing in our Slovak villages" [my translation].

[2] Certainly, errors can be of various degrees. In high school, I remember trying to locate on a map of today's Poland the somewhat mysteriously named city of Preszburk that was mentioned in my history textbook. Despite the evidently Polish spelling of its name I could not find it, and only years later did I learn that it was Bratislava. Prior to 1918 the present-day Slovak capital was officially known as Pozsony in Hungarian and Preßburg in German. It was the latter form which gave rise to the Polonized form Preszburk. On the other hand, some authors using current forms of placenames in order to talk about the past have problems with matching some smaller localities with the present-day forms of their names. For instance, Żukowski speaks consistently about Wrocław in the 18th-century context though it was known as Breslau then, but sticks to Pless (i.e. Pleß), which is Pszczyna today (1994: 69). 
[3] Obviously, Central Europe was to a certain degree influenced by Byzantine Greek, Old Church Slavonic and Osmanlica that were used in Eastern Europe and South-Eastern Europe, but that problematic is beyond the scope of this article.

[4] Before the 16th century one's name was written down in a Latinized form as was the case with place-names, but with the rise of interest in Antiquity one also tended to translate one's name into Latin.

[5] Breslau's (Wrocław) aldermen opposed the widespread use of the Ptolemaic form of the name of their city and championed the Latinized form Wratislavia, which emperor Charles V officially recognized in 1530 (Conrads, 1994: 252-3).

[6] Latin or Greek forms of Silesian place-names were often used by students during their matriculation examinations (Conrads, 1994: 251).

[7] The parts of Silesia gained by Prussia became known as Prussian Silesia. It consisted of the regions of Lower and Upper Silesia.The fragment of Silesia (mostly the southern sliver of Upper Silesia) that remained with Vienna was dubbed Austrian Silesia and comprised two territorially discontinuous parts of West and East Silesia.

[8] Akin to Bohemian but steeped in the dialects of Moravia.

[9] The three ethnic groups were concentrated in Upper and Austrian Silesia (see Kamusella, 2000a).

[10] Nowadays, the city's name is Zabrze again, but it is good to remember that the official German pronunciation of the name before 1915 was /tsabrtseh/ while Poles pronounce it / zabzheh/. The difference in pronunciation is the result of reading the graphic representation of the city's name in accordance with the different rules of the German and Polish languages governing phonetic realization of the same Latin-alphabet graphemes.

[11] This dictionary also contains Polish and German versions of the placenames in Poland's section of East Silesia.

[12] This dictionary also contains German and Polish versions of the placenames in the small fragment of Saxony, which was cut away from Germany following the Oder-Neisse line, and today forms the very south-western corner of Poland.

[13] The western section of Upper Silesia that remained in Germany after the division of this region in 1922.

[14] In the past, Jews, having usually been more literate than the average inhabitant of Central Europe, developed a whole system of Yiddish forms of the place-names of the localities where they lived and 
wrote them down in Hebrew characters (cf. Adamczyk-Garbowska, 1994: 167).

\section{REFERENCES}

Adamczyk-Grabowska, Monika. 1994. Polska Isaaca Bashevisa Singera. Lublin, Poland: Wydawnictwo Uniwersytetu Marii Curie-Skłodowskiej.

Anderson, Benedict. 1991. Imagined Communities: Reflections on the Origin and Spread of Nationalism. London: Verso.

Anon. 1905 Slezsko (XXIII: 365-389). In: Ottův slovník naučny. Prague, AustriaHungary.

Armstrong, John A. 1982. Nations Before Nationalism. Chapel Hill, NC: University of North Carolina Press.

Barran, Fritz R. 1993. Städte-Atlas. Schlesien. Leer, Germany: Rautenberg.

Batowski, Henryk. 1964. Stownik nazw miejscowych Europy Środkowej $i$ Wschodniej XIX i XX wieku. Warsaw: PWN.

Battek, Marek J. \& Joanna Szczepankiewicz. 1998. Stownik nazewnictwa krajoznawczego. Polsko-niemiecki, niemiecko-polski. Wrocław, Poland: Silesia.

Berger, Stefan et al., eds. 1999. Writing National Histories: Western Europe Since 1800. London: Routledge.

Billig, Michael. 1995. Banal Nationalism. London: Sage.

Breuilly, John. 1993. Nationalism and the State. Manchester: Manchester University Press.

Choroś, Monika \& Łucja Jarczak. 1995. Słownik nazw miejscowych Dolnego Ślaska. Polsko niemiecki i niemiecko-polski. Opole, Poland: Instytut Śląski.

Monika, Łucja Jarczak \& Stanisława Sochacka. 1997. Stownik nazw miejscowych Górnego Śląska. Polsko-niemiecki i niemiecko-polski. Opole, Poland: Instytut Śląski \& Kluczbork, Poland: Księgarnia Minerva.

Conrads, Norbert, ed. 1994. Schlesien. Berlin: Siedler.

Crystal, David. 1987. The Cambridge Encyclopedia of Language. Cambridge: Cambridge University Press.

Davies, Norman. 1999. The Isles: A History. London: Macmillan.

Deutsch, Karl W. 1966. Nationalism and Social Communication: An Inquiry into the Foundations of Nationality. Cambridge, MA: The MIT Press.

Edwards, John. 1994. Multilingualism. London: Routledge.

Eichler, Ernst. 1987-. Slawische Ortsnamen zwischen Saale und Neisse. Ein Kompendium (2 vols. published so far, A-J, K-M). Bautzen, East Germany: Domowina-Verlag. 
Enriquez, Juan. 1999. “Too Many Flags?” Foreign Policy. No. 116, Fall: 30-49.

Fishman, Joshua. 1996. "Language and Nationalism." In: Stuart Woolf, ed. Nationalism in Europe 1815 to the Present: A Reader. London: Routledge: 155-170.

Foucault, Michael. 1977. The Archeology of Knowledge. London: Tavistock.

Gann L. H. \& Peter Duignan, eds. 1969. Colonialism in Africa 1870-1960. Vol. 2. Cambridge: Cambridge University Press.

Gellner, Ernest. 1983. Nations and Nationalism. Oxford: Blackwell.

Gregor, J. 1905. Mapa Górnego Śląska z uwzględnieniem stosunków językowych, granic powiatowych i kolei żelaznych. Nicolai, Germany: K. Miarka.

Haardt, W. \& B. Gustawicz. c. 1907. Kozenna Atlas Szkolny. Vienna: Edward Hölzl geographisches Institut.

Andrzej Hanich. 1997. Skorowidz nazw miejscowości diecezji opolskiej. Polskoniemiecki i niemiecko-polski. Opole, Poland: Solpress.

Hobsbawm, Eric J. and Terence Ranger, eds. The Invention of Tradition. Cambridge: Cambridge University Press.

Hosák, Ladislav and Rudolf Šrámek. 1970-1980. Místní jména na Moravě a ve Slezsku (2 vols.). Prague: ČSAV.

Hroch Miroslav. 1985. Social Preconditions of National Revival in Europe: A Comparative Analysis of the Social Composition of Patriotic Groups among the Smaller European Nations. Cambridge: Cambridge University Press.

Huntington, Samuel P. 1996. The Clash of Civilizations and the Remaking of World Order. New York: Simon \& Schuster.

Kaemmerer, M. 1988. Ortsnamenverzeichnis der Ortschaften jenseits von der Oder und Neisse. Leer, Germany: Rautenberg.

Kamusella, Tomasz. 1999. "Język a Śląsk Opolski w kongtekście integracji europejskiej." Śląsk Opolski. No. 3: 12-19.

Tomasz. 1999a. "Ethnic Cleansing in Silesia 1950-89 and the Ennationalizing Policies of Poland and Germany." Patterns of Prejudice. No. 2.: 51-73.

Tomasz. 2000 [forthcoming]. "Język jako instrument nacjonalizmu w Europie Środkowej i Wschodniej." In: Bernard Linek \& Kai Struve, eds. Nowoczesny nacjonalizm a identyfikacja narodowa w Europie Środkowej i Wschodniej. Opole: Instytut Śląski.

Tomasz. 2000a [Forthcoming]. "Wyłanianie się grup narodowych i etnicznych na Śląsku w okresie 1848-1918." Sprawy Narodowościowe. No.1.

Kann, Robert A. \& Zdeněk V. David. 1984. The Peoples of the Eastern Habsburg Lands, 1526-1918. Seattle, WA: University of Washington Press. 
Kedourie, Elie. 1993. Nationalism. Oxford: Blackwell.

Kohn, Hans. 1962. The Age of Nationalism: The First Era of Global History. New York: Harper \& Row.

Kushner, Tony and Ken Lunn. 1997. "Memory, Forgetting and Absence: The Politics of Naming on the English South Coast." Patterns of Prejudice. No. 2: 31-49.

Kužel, Stanislav. 1999. "Hranice obce jako rozhraní pro interpretaci konfesního střetu i ‘národnostní' aktivity.” Český lid. No. 2: 133-46.

Lakoff, George and Mark Johnson. 1980. Metaphors We Live By. Chicago: The University of Chicago Press.

Magocsi, Paul Robert. 1995. Historical Atlas of East Central Europe. Seattle, WA: University of Washington Press.

Malicki, Jan.1987. Początki sporów o polskość i niemieckość Ślaska. Katowice, Poland: Muzeum Śląskie.

Mrass, Peter. 1995. Mapy Górnego Śląska/Landkarten Oberschlesiens. Opole, Poland: Biblioteka Publiczna \& Ratingen-Hösel, Germany: Stiftung Haus Oberschlesien.

Olesch, Reinhold. 1958/1959. Der Wortschatz der polnischen Mundart von Sankt Annaberg (2 vols.). (West) Berlin: Freie Universität Berlin \& Wiesbaden, West Germany: Otto Harrassowitz.

Pfohl, Ernst. 1984 [1932]. Ortslexikon Sudetenland. Nuremberg: Preußler.

Pierson, Christopher. 1996. The Modern State. London: Routledge.

Potter, David M. 1962. "The Historian's Use of Nationalism and Vice Versa." American Historical Review. No. 67: 924-50.

Schulze, Hagen. 1991. The Course of German Nationalism: From Frederick the Great to Bismarck 1763-1867. Cambridge: Cambridge University Press.

Stewart, George R. 1970. A Concise Dictionary of American Place-Names. New York \& Oxford: Oxford University Press.

Stoob, Heinz and Peter Johanek, eds. 1995. Schlesisches Städtebuch (Ser.: Deutsches Städtebuch, Vol. 1). Stuttgart, Germany: Kohlhammer.

Stüttgen, Peter, Helmut Neubach and Walther Hubatsch. 1976. Grundriß zur deutschen Verwaltungsgeschichte 1815-1945 (Ser. A: Preußen ed. by Walther Hubatsch, Vol. 4: Schlesien). Marburg (Lahn), Germany: Johann-Gottfried-Herder-Institut.

Sugar, Peter F. 1977. Southeastern Europe under Ottoman Rule, 1354-1804. Seattle, WA: University of Washington Press.

Wickham, Chris. 1997. "Introduction: What's in a Name?" Patterns of Prejudice. No. 2: 3-5. 
Wolf, Eric R. 1982. Europe and the People Without History. Berkeley, CA: University of California Press.

Żukowski, Arkadiusz. 1994. W kraju złota i diamentów. Polacy w Afryce Potudniowej XVI-XX w. Warsaw: PWN.

Tomasz Kamusella, Opole University, Opole, Poland 